\title{
Personalized Education Approaches for Chemical Engineering and Relevant Majors
}

\author{
Feng-qing Zhao \\ Chemical Department of Hebei University of Science \& Technology, Shijiazhuang 050018, PR China
}

\begin{abstract}
Personalized education has drawn increasing attention in universities these years. With the purpose of improving the students' comprehensive ability and developing teaching strategies to ensure students' education is tailored to their needs, we proposed Three-Stage Approach (TSA) to enhance personalized education for chemical engineering and relevant majors: professional tutorial system--equipping with professional guidance teachers for freshman students to guide their learning activities and provide professional guidance; open experimental project-setting up open experimental projects for sophomore and junior students to choose freely; individualized education module--setting up 10 different individualized education modules for senior students to select. After years of practice, the personalized education model is improved day by day and proved effective and fruitful.
\end{abstract}

\section{Introduction}

Personalized education is a teaching and learning approach which is centred on the needs, aptitudes, and interests of individual students. It has got increased popularity in the last 15 years or so in a number of countries including United Kingdom, United States of America, Australia, New Zealand and China. It has been promoted as a key learning approach to prepare young people for the demands of the twenty-first century and the expectations placed on them by society [1].

Personalized education emphasizes the main position and the motivation of their subjective initiative. The educated acquire knowledge and enhance the ability through their active participation [2]. Personalized education, showing sufficient respect for the individual differences and personal willingness, pays attention to the main role of the students' personality in education, which is conducive to the development of the intellectual potential of the students and the improvement of their creative ability. Personalized education is to achieve the goal of self-development and self-exceeding of individuals on the basis of general education. With this concept of education, the individual is no longer a passive recipient who takes understanding, accepting and adapting the socio-culture as the sole purpose of education, but a person with sound personality, creativity and pioneering talent who is bound to meet the needs of the society through education, turning "want me to do" into "I want to do". It should be stressed that the personalized education should meet the social demands for talents, but also respect and develop the students' personality, so that each student gives full play to their creativity by meeting the requirements of the society. The personalized education and general education are like the "required action" and "freestyle" in gymnastics, both of which are interrelated and mutually reinforce, deserving to be balanced [3].

The Outline of China's National Plan for Medium and Long-term Education Reform and Development (20102020) says universities at all levels should 'innovate and reform talents training modes' and 'explore a variety of training modes'. Responding to this requirement, we came up with personalized education as an important way to put forward the innovation and reform of talents training modes [4-5]. Launched in 2005, the reform practice of personalized education has been actively and innovatively promoted until a system was finally formed with a clear goal, of distinct characteristics and rich in both contents and forms [6].

In order to improve students' comprehensive quality, we are going further to develop a Three-Stage Plan with the characteristics of specialties on the basis of a large amount of research and years of practice. The approaches in TSA can effectively improve students' innovation ability and practice ability and thus, help the cultivation of the professional quality and engineering practice ability of chemical and pharmaceutical engineering students.

\section{Personalized education strategies and approaches}

Developing the characters of college students and stimulating their creativity is the trend of higher education. To make students adapt to the society, the local universities are required to implement personalized 
education, develop innovative education, cultivate highquality and innovative talents. The essence of personalized education is "student-centred" education. When carrying out personalized practical strategies, priorities should be set to reforming the traditional teaching mode, establishing the system of personalized training system and constructing the teachers' team as well as creating a relaxed and open teaching environment. Through years practice, we set up a TSA plan in implanting the personalized education for chemical and pharmaceutical engineering Majors.

\subsection{Assign professional tutor for students as the entrance to the university}

Tutorial system was an innovative measure for the cultivation of the undergraduate proposed by the university in 2006 , the core value of which is "personal growth" system is embodied in the "tutorial system", which is currently the most complete system for the personalized education. Under this tutorial system, the students receive individual instruction in major; guidance ideologically and in life, psychological counselling and all-round development, thus the tutorial system has become a "guiding man" to guarantee the healthy growth of the students. The tutors' duties include assisting students in their courses selection, helping students make their personal development plan in university even the life plan, conducting regular discussions and counselling.

Four documents are designed for this program, the main contents is listed in Table 1 .

Table 1. Documents in personal tutor project.

\begin{tabular}{|l|l|}
\hline \multicolumn{1}{|c|}{ Document } & \multicolumn{1}{c|}{ Content } \\
\hline $\begin{array}{l}\text { Student information } \\
\text { registration form }\end{array}$ & $\begin{array}{l}\text { The name, gender, nationality, class, home address, telephone number, expertise, hobbies, family } \\
\text { members and resume. }\end{array}$ \\
\hline $\begin{array}{l}\text { Students' individual } \\
\text { growth training } \\
\text { program }\end{array}$ & $\begin{array}{l}\text { Personal occupation ideal, } \\
\text { Research field of interest, } \\
\text { Environment and the difficulties faced, } \\
\text { Training plan design }\end{array}$ \\
\hline Tutor work records & $\begin{array}{l}\text { Name of students, guiding place, guidance form, records, summary of the work and the supervisor's } \\
\text { signature }\end{array}$ \\
\hline Assessment form & $\begin{array}{l}\text { The assessment item, the evaluation of students by tutor and score, including: } \\
\text { Ideological and moral, } \\
\text { Academic and learning, } \\
\text { Self-planning in occupation, } \\
\text { Individualized training, } \\
\text { Participation in extracurricular activities and practice. }\end{array}$ \\
\hline
\end{tabular}

\subsection{Open experimental projects for sophomore and junior students}

Open experimental projects are usually designed for sophomore and junior students to choose freely. Open experimental projects generally refers to that the experiment project is not provided by the teacher in advance, but by the students from their professional characteristics, hobbies and learning situation. The students independently carry out corresponding experimental activities under the teacher's appropriate guidance. At present, the open experimental projects in our college include following three types:

- Experimental projects provided in innovative open laboratories, which are most often national or provincial key labs. Some specially set up laboratory which managed by the students are used for this purpose.

- Research projects come from the national, provincial and university, or from community activities, personal hobbies. The students organize research groups to complete independently research project using the experimental facilities in the laboratories.

- Students, as members of the project group, are directly involved in teachers' research projects, mostly undertake one sub-projects. Of course, these were implemented in the tutors' research labs.
Specially, Hebei University of Science and Technology gives "Science and Technology Innovation Fund Project for College Students" project every year. In 2014, 510 projects were declared in 2014, and nearly $90 \%$ of them were approved and can get scientific and technical funds financial support. In order to guarantee the smooth implementation and achieved substantial results for the innovation fund projects, some measures were outlined. The Fund for the project is divided into stages, after the start of the project and the end of the project. $50 \%$ of the fund was allocated each stage. Those projects completing with patent application (including software copyright rights registration) and paper publishing, the first author must be the student, not the tutor. All the project must be examined through expert review (expert review by the university academic committee). If needed, project evulation and review meeting is held. The students make a report about the implementing process and results obtained, the expert group consisting of teachers and students evaluate the project. The Pass rate is about $90 \%$, while the other $10 \%$ were rejected and continue to further improved.

\subsection{Module setup of personalized education for chemical engineering and relevant majors.}


In the process of personalized education practice, we kept modifying and adjusting the education approach as well as expanding its dimensions in order to suit the major requirements and students' and personal interests. We set up 10 personalized education modules with 15 affiliated personalized education groups. Students can choose which group to join in on the basis of their personal interests. In each group, the tutors are responsible for the implementation of the experiments and the assessment of students' performances. Table 2 gives the current modules for personalized practice for chemical engineering and relevant specialties in Hebei University of Science and Technology.

It should be noted that the internship module might continue until graduation. In this period, the students can be put to work in a plant, taking parts in the actual production activities. First, they are given a three-level (plant, workshop and group level) safety education and training which teaches safety knowledge, production process, work content and precautions After that, the workshop and the human resources department make a joint decision after discussion on which posts these students should be assigned to. Once taking their posts, these students get into a "one-to-one" pattern (A skilled worker is assigned to a student as his/her tutor). Over the whole practice period, a student is usually arranged to work in 2-4 different production sections where he/she must master the technological processes of each section, get familiar with the corresponding operations, and write the internship summary.

Table 2. Current modules for personalized practice.

\begin{tabular}{|c|c|c|}
\hline Module & Content & Major \\
\hline $\begin{array}{l}\text { Professional } \\
\text { development }\end{array}$ & $\begin{array}{l}\text { Join in the research work of the tutors, finishing literature search, } \\
\text { experiment design and planning. }\end{array}$ & $\begin{array}{c}\text { Chemical engineering; } \\
\text { Pharmaceutical Engineering; } \\
\text { Pharmacy; } \\
\text { Pharmaceutical preparation }\end{array}$ \\
\hline $\begin{array}{l}\text { Professional } \\
\text { skills }\end{array}$ & $\begin{array}{l}\text { Study in pharmaceutical preparations training base where real } \\
\text { pharmaceutical process is simulated. }\end{array}$ & $\begin{array}{l}\text { Pharmacy; } \\
\text { Pharmaceutical preparation }\end{array}$ \\
\hline $\begin{array}{l}\text { Software } \\
\text { applications }\end{array}$ & $\begin{array}{l}\text { Focusing on study of Aspen Plus, a process simulation tool, and Gaussian, } \\
\text { a molecular simulation software. }\end{array}$ & $\begin{array}{l}\text { Chemical engineering; } \\
\text { Pharmacy; }\end{array}$ \\
\hline $\begin{array}{l}\text { Design } \\
\text { experiment for } \\
\text { Unit operations }\end{array}$ & $\begin{array}{l}\text { Teachers propose goals of experiments; students write project plans, make } \\
\text { preparations, install devices, make equipment, sort data, and finally write } \\
\text { lab reports. }\end{array}$ & $\begin{array}{l}\text { Chemical engineering; } \\
\text { Pharmaceutical Engineering; } \\
\text { Pharmacy; } \\
\text { Pharmaceutical preparation }\end{array}$ \\
\hline $\begin{array}{l}\text { Comprehensive } \\
\text { design }\end{array}$ & $\begin{array}{l}\text { Students conduct operations to form a chemical system, such as } \\
\text { installation, pressure testing, leak testing, draw equipment and piping } \\
\text { layout of device. }\end{array}$ & $\begin{array}{l}\text { Chemical engineering } \\
\text { Pharmaceutical Engineering }\end{array}$ \\
\hline Project fe & $\begin{array}{l}\text { Market demand forecast, production scale, technology \& equipment \& site } \\
\text { selection, project implementation, environment protection and safety, } \\
\text { economic evaluation. }\end{array}$ & $\begin{array}{l}\text { Chemical engineering } \\
\text { Pharmaceutical Engineering }\end{array}$ \\
\hline $\begin{array}{l}\text { Internship in } \\
\text { factories }\end{array}$ & $\begin{array}{l}\text { Students go to work in a plant, taking parts in the actual production } \\
\text { activities. }\end{array}$ & $\begin{array}{l}\text { Chemical engineering; } \\
\text { Pharmaceutical Engineering; } \\
\text { Pharmaceutical preparation }\end{array}$ \\
\hline Safety evaluation & $\begin{array}{l}\text { Basics of safety, safety assessment criteria and how to compile engineering } \\
\text { design documents in the actual process of safety evaluation. }\end{array}$ & $\begin{array}{l}\text { Chemical engineering; } \\
\text { Pharmaceutical Engineering; } \\
\text { Pharmacy; } \\
\text { Pharmaceutical preparation }\end{array}$ \\
\hline $\begin{array}{l}\text { Instrumental } \\
\text { analysis }\end{array}$ & $\begin{array}{l}\text { Learn to use gas chromatography, liquid chromatography, infrared } \\
\text { analysis, UV analysis, DTA, atomic absorption, XRD and XEM, etc. }\end{array}$ & $\begin{array}{l}\text { Chemical engineering; } \\
\text { Pharmaceutical Engineering; } \\
\text { Pharmacy; } \\
\text { Pharmaceutical preparation }\end{array}$ \\
\hline $\begin{array}{l}\text { Basic knowledge } \\
\text { strengthening }\end{array}$ & Deepening the knowledge of Unit operations by selected case studies. & $\begin{array}{l}\text { Chemical engineering; } \\
\text { Pharmaceutical Engineering }\end{array}$ \\
\hline
\end{tabular}

\section{Results and discussion}

In the period of implementing personalized education, the students' interest in learning was remarkably aroused. Significant results were obtained.

The students completed, in the past three years, more than 120 extracurricular scientific and technological projects and won 18 state-level awards and 30 province level achievements, among which, include 1 first prize and 1 second prize in "Challenge Cup" National Science and Technology College of Extra-curricular Academic Works Competition, which is one of the top level academic contest for Chinese university students. Besides, the achievement in taking part in scientific contests, such as, "National University Energy Saving and Pollution Reduction" and "Mitsui Cup" National University Chemical Design Competition is outstanding.

The students are satisfied with personalized education approach. Their satisfaction was measured via openended questions. In June 2014, a sample survey was performed on the effect of personalized education approach in 580 participating students. Of them, 521 students recognized the value of this approach. Only 14 students expressed no opinion on, or were not dissatisfied with this approach. But most of them suggested that this approach is good for them in seeking jobs. Almost all the 
participating students gave positive evaluative comments. As a student put it, "It was great to get some experience with personalized education approach, I can do what I please; It was really fun." [7]

Above 98 percent of students took part in various scientific activities, and finished 56 China national patent applications, including 26 patents of invention and 30 patents of utility model in 2012-2014. Some of these patents have found practical applications and made remarkable economic and social benefit. Besides, more than 200 research papers, the students as first author, were published in academic journals, in which over $30 \%$ were cited in Science Citation Index Expanded or EI Compendex web.

With the implementation of personalized education, the students' overall ability was obviously improved. The employment rate is an index closely related with education method. According to statistics, the employment rate (including those pursue further study) of the graduates of our department in the three consecutive years (2011-2013) was more than 95\%, ranking among the tops of similar universities in China.

After years of practice, although positive results were obtained, there are still much left to do in the future for TSA approach.

Firstly, lack of matched incentive policies, the teachers' enthusiasm as professional tutor for students as the entrance to the university is not so high.

Secondly, there exhibited uneven participation situation among the 10 education modules for students, some modules, for example, basic knowledge strengthening module, draws a major of the students annually, while the professional development module seems unwelcomed by the students, which draws only $5 \%$ student to participate every year. The quantity and types of instruments are still limited in instrumental analysis module, which cannot satisfy the need of different majors.

Thirdly, the independent innovation laboratories which equipped with various devices and accessories are not sufficient. Most students applied for this module have to carry out the project in the research labs of the tutors.

Last but not the least, the organization and management of TSA approach is still need to be improved. We have set up a management system, led by the dean of the college and joined by every department director. In the future, we will to let more off-campus specialist, outstanding alumni and the students in college take part the organization and management. If possible, we will try to corporate with production enterprises, design institute and research institutions in implementation personalized education.

\section{Concluding remarks}

China is now vigorously promoting the Excellent Engineer Training Program and Engineering Education Accreditation, the former is initiated by the Ministry of Education with the aim of producing millions of graduates with top engineering talent within a decade. The latter is moved by China Engineering Education
Accreditation Association, which is authorized by the Ministry of Education as the only legitimate organization to conduct engineering educational accreditation in China, aiming to promote international accreditation of Chinese engineering education and to establish sound foundation for international competition for engineering talents. In the implementation of these works, we studied the contents and development trend of the professional accreditation standards in international engineering education, and developed a professional accreditation standards for Chemical engineering and technology major late in 2015, aiming at improving the quality of engineering education and realizing the essence of equivalent. China's engineering education professional accreditation standards includes two standards: general standard and professional supplemented standard. The former is the requirement that all the engineering majors should comply with, and the latter is the specific requirements for different professional characteristics on the basis of the former. In recent years, we have been exploring the personalized education approaches in chemical engineering and relevant majors according to the requirements of professional accreditation and Excellent Engineer Training Program. The combination of personalized education program, Excellent Engineer Training and professional certification, greatly improved the quality of education for chemical engineering and relevant majors.

As an important idea of higher education and teaching reform, personalized education has found its way to the whole teaching process of the faculty of our college. With years of exploration and practice, a personalized education mode and operating mechanism which benefit our courses has taken shape initially, with a positive atmosphere gradually built for the implementation of its educational ideas, of which student-centeredness has also won our faculty's recognition. But we have already clearly recognized that personalized education activities are carried out according to students' different personalities, and the students' differences in personalities and needs make personalized education a complex work of teaching, the form and content of which need to be adjusted and updated at any moment if necessary. Therefore, we should be careful to stay student-oriented, recognizing their individual differences, respecting their individual needs, focusing on their personality development, exploring their personal potential, constantly improve their practical ability and professional quality, and fully develop their scientific quality and innovation, so as to promote the development of personalized education which fosters students' creative and innovative talents.

In this paper, we proposed Three-Stage Approach to enhance personalized education for chemical engineering and relevant majors: professional tutorial system-equipping with professional guidance teachers for freshman students to guide their learning activities and provide professional guidance; open experimental project--setting up open experimental projects for sophomore and junior students to choose freely; individualized education module--setting up 10 different 
individualized education modules for senior students to select. A lot of positive results were obtained in the implementation of this approach. It is proved good for the students. Just as I stated above, there are still much left to be improved, nevertheless, the future is bright for this approach.

\section{Acknowledgements}

In this paper, I would like to show the best grateful to Mr. Yifeng Yu, Xinyu Rong, Zhao Ma, Ran Liu, Jie Yao, Sugai Cao,Zhiguo Zhanmg and Shaojie Liu as they had given a lot of valuable ideas and support to the experiments, which made a great contribution to the paper.

\section{References}

1. Bentley, T. "Personalised learning in the UK: from vision to strategy? " (Personalised learning: high expectations symposium, Department of Education and Training, Sydney.2005)
2. X. Hao, W. Shen, W. Cong, The implementation of personalized education to enhance the quality of personnel training, China Adult Education, 2,11 (2013)

3. F. Zhao, Z. Ma, Promoting the Innovative Personnel Cultivation System of Local Universities. (Eastern Academic Forum, Australia. 2015)

4. W. Ji, Education mode and validation of local college personalized construction, Journal of Hebei University of Science and technology (Social Sciences), 13,1(2013)

5. W. Ji, Practice verification of the value of individualized education and deepening approach, Journal of Hebei University of Science and technology ( Social Sciences), 11,82(2011)

6. X. Liu. Exploring the personalized education system of undergraduate students, Research on Higher Engineering Education,6,105(2012)

7. F. Zhao, Y. Yu, S. Reng, S. Liu, X. Rong, Improving Engineering Practice of Chemical and Pharmaceutical Engineering Majors In Chinese Universities, J. Chem. Educ., 91,2(2014) 